\title{
ПРИСУСТВО И КАРАКТЕРИСТИКЕ РАЗГОВОРНОГ СТИЛА У НЕОБЈАВЉЕНОМ РУКОПИСУ КЊИГА СЕЋАҢА
}

\begin{abstract}
Предмет истраживања представља присуство разговорног стила у необјављеном рукопису Књига сећања (Учитељска школа у Јагодини 1920-1940. у сећању њених ученика).

Стилски разнолики текстови у раду се анализирају са аспекта доминантних карактеристика које их повезују. Пре свега, то су мање или више литерарно уобличена приватна дневничка сведочења или мемоарске цртице. Текстови показују и известан степен стилске и функционалностилске кохерентности с обзиром на то да су њихови аутори сличних година, истог образовања и претежно мушког пола. Показује се да је разговорни језик младих образованих људи тога доба (између два светска рата) у великој мери ослоњен на стандардни српски језик, да показује исвестан степен белетризованости, са немалом дозом еуфемизације, која за циљ има елиминисање вулгаризама и директног упућивања на непожељне чињенице.
\end{abstract}

Кључне речи: разговорни стил, језичка култура, дијалог, узречице, обраћање, еуфемизми.

\section{1. Уводне напомене}

Предмет овог рада јесу присуство разговорног стила и његове карактеристике у необјављеном рукопису Књига сећања (Учитељска школа у Јагодини 1920-1940. у сећању њених ученика). Књига сећања је документ који је, прикупивши текстове ученика који су похађали Учитељску школу у Јагодини између два рата, формирао Драгиша Марковић. ${ }^{1}$ Састоји се од забелешки анегдотског, мемоарског и дневничког карактера, кратких текстова који су

\footnotetext{
*ilijana.cutura@gmail.com

** Рад је настао у оквиру пројекта 178014 Динамика структура савременог српског језика, који финансира Министарство просвете, науке и технолошког развоја Републике Србије.

${ }^{1}$ Драгиша Марковић рођен је у Сењу код Ћуприје 1919. године, а преминуо 2011. у Београду. Јагодинску Учитељску школу завршио је 1938. Кьигу сећања, своју приватну преписку са Драгишом Марковићем, уступио нам је професор Нинослав Станојловић, историчар.
} 
објављени у педагошким гласилима и новинама. ${ }^{2}$ За анализу су издвојени само текстови дневничког и анегдотског карактера, који обилују наративним и дијалошким секвенцама.

Циљ анализе јесте да се истраже основне карактеристике разговорног стила специфичне социјалне групе (ученика Учитељске школе) тога доба.

Сам разговорни стил изазива, како Силић каже, низ недоумица, те је ,jедан од честих методолошких 'камена спотицања'” (2006: 110). Како су „говорни и писани језик образованог човека увек два донекле посебна лингвистичка система" (Ивић 1997: 154-155), а реч је о писаним текстовима образованих људи, треба истаћи да је немогуће утврдити време настанка одређених текстова, постојање или непостојање намере да Кюига једном буде и објављена, и - на крају - степен редакторских корекција. Стога у раду имамо на уму да се ради о реконструкцији разговорног стила представљеног само у делу текстова заступљених у рукопису. Друго, у делу текстова који су обележени белетризацијом свакако се ради о стилизованом разговорном функционалном стилу. Такве текстове смо искључивали из анализе.

Писана реализација разговорног стила јавља се у записима, писмима, белешкама, а данас и у кратким смс порукама, електронским ћаскаоницама, на друштвеним мрежама и сл. Садржај писане реализације разговорног стила је, као и код усмене, „свакодневни живот - у најширем смислу” (Силић 2006: 109). Као основне одлике стила Тошовић издваја ненормативност и некодифицираност (2002: 311), али каже: „Слично бонтону, вербалну комуникацију регулише говорна етикеција [...] Овим питањима бави се култура говора/језика (говорна/језичка култура), реторика и стилистика” (Тошовић 2002: 311; о проблемима нормирања лексике разговорног стила в. Ристић 2006: 53-64).

У раду се показује да се разговорни стил представљен у нашем корпусу одликује високом блискошћу са стандардним језиком. Заступљен је, у највернијем облику, у забележеним дијалозима који у аутобиографским текстовима (и усменим казивањима) захтевају „веома јак утисак о читавој слици ванлингвистичке ситуације у којој се остварио говор да би добио своје навођене облике у дискурсу. Најопштија карактеристика те ситуације је контраст: учених и неуких, и њихов мудри говор, као у комуникацији младих и старих, наставника и ученика, и сл. Затим контраст између претходних и потоњих догађаја, опажаја и импресија" (Половина 1999: 134). Управо на оваквој сиени одвијају се забележени дијалози у Књизи сећања.

Додатно, уколико сиену схватимо као „,'психичко окружење' или културом одређене прилике” (Хајмз 1980: 102) у којима се одвија комуникација, можемо уочити да се окружење (као физички оквир у којем се комуникатори налазе) и сцена стапају. Наиме, интернатски живот (у приземљу школске зграде биле су школске просторије, а на спрату интернатске) и стално присуство професора, васпитача и директора (који је живео у кући уз саму

\footnotetext{
${ }^{2}$ Начин организације текстова не омогућује да се наведу бројеви страна на којима се налазе примери наведени у раду.
} 
школу) условљавали су непрестано „мешање” приватног и професионалног односа, присног и службеног, свих актера у комуникацији, што ће се примерима и потврдити.

Одлике Къиге сећања које у раду представљамо, а које потврђују да специфичност сцене и окружења пресудно утичу на језик свакодневне комуникације, јесу дијалози, присуство дијалекта, узречица и поштапалица у њима, начини обраћања и ословљавања, специфична лексика и устаљени изрази.

\section{2. Дијалози у рукопису Къига сећања}

Иако у дијалозима и целокупним текстовима, како смо већ напоменули, преовладава језик који је потпуно близак стандардном, аутори текстова верно преносе и нестандардне идиоме у једној средини која је пуна дијалекатског и језичког „шаренила”. ${ }^{3}$

Чести записи о несташлуцима и реакцијама професора и васпитача обилују кратким екскламативним, често и елиптичним заповедним реченицама, као и реторским питањима. Реторска питања често служе за исказивање говорног чина прекора, како потврђују следећи примери:

Ми умало да повиленимо од радости, но иза нас грмну познати глас: - Шта тражиmе овде? Напоље!; После ме Чика Рака грдио (није ме тукао, као што се некима десило) : - Срам те било!; - Донеси иртеж! каже наставник. Ја не донесем; - Код директора! викну он; Не слушајући нас, васпитач Арса грмну још жешће: Напоље! Напоље! Срам вас било, лажови једни, преваранти. Досад сте скитали, а сад још овде лажете!

Позове ме директор Петровић: - Шта ти то радиш на часу иртања?; Стојимо збуњени у очекивању страшног суда. Дојури однекуд служитељ и дрекну: - Ко је разбио прозор?; - Шта ти би?! чуди се он. - Зашто побеже, побогу?

У дијалозима су честе узречице, поштапалице и форме заклињања. У том смислу, рукопис не показује значајну разлику у односу на данашњи разговорни стил нити по фреквенцији ових елемената нити по њиховом инвентару. Такве форме - заклетве, узречице (узвике) море и бре, и сл. - Николић (2008) обједињује термином поштапалище и каже: „Пошто изражавају афективно расположење или субјективни однос према предмету о коме се говори, поштапалице имају пре свега реторичку и стилистичку вредност" (Николић 2008: 104). У нашем корпусу налазимо вала, море, (u) бре, богме, врага му, потом заклињања мајке ми и живота ми:

- Вала ово још нисам видео у свом веку, рече старији човек у сукненом оделу, са врнчаним опанцима; Море, пријатељу, поштеније је и овако; Море, лако је њему; Море, стиже друг; Е јеси, бре, права врдалама; - Вечера је, бре, завршена! рекох ја, више за себе; И бре, немам ситно, како да ти вратим кусур;

\footnotetext{
${ }^{3}$ Поред ученика из Поморавља, у школи је било и ученика из свих крајева Србије, из Македоније, Далмације. Запослени су били различитих профила - од професора са докторатима до служитеља и куварица чији је говор пренет у дијалозима.
} 
Ти странци су, богме, били Енглези; - Како? Како то, врага му, „на опрези”, прекиде ме професор;

- Тетка Мицо, вечера је издата пола сата раније, ја имам тачан сат, ево видите, најтачнији у интернату, мајке ми, понављао је Гиле, држећи сат у руци; Нисам, живота ми, све што нађем, ја пријавим.

Партикула $м a$ јавља се у корпусу у иницијалној реченичној позицији, као сигнал емфатички израженог, јасно реактивног неслагања (као у примеру „Ma ајде, шта ти пада на памет”). Посебан емоционални набој изражава се у ситуацијама када је говорник „потпуно запањен [...] или бар под интензивним утиском изненађења удруженог с неверицом” (Ивић 2005: 91).

У дијалозима су документовани и начини обраћања, који су у разговорном функционалном стилу „често први сигнал формалности или неформалности” (Кликовац 2008: 120). Ученици се професорима обраћају са (господине) професоре, директору са господине директоре. Осталим запосленима обраћају се сходно њиховој функцији у школи и интернату, али и степену блискости, на пример куварици:

Ко без душе банусмо у празну трпезарију и без оклевања протурисмо главе кроз шубер кухиње, дозивајући у дуету: - Тетка Мицо, тетка Мицо!

И комуникација у другом смеру је слична. Док се професори ученицима обраћају углавном презименом (ређе именом), економ ће, на пример, једном од ученика рећи:

Па ти, ирни сине, не плаћаш интернат, избациће те...

Ученици се једни другима обраћају надимком или властитим именом (које у разговорном функционалном стилу, осим референцијалне функције, може имати и друге семантичке интерпретације, в. Савић/Половина 1989: 7-9), али често употребљавају именицу друг или друшкан као елемент њиховог специфичног жаргона:

Знаш, друшкане, сат и жена се ником не дају.

Именицу друг, међутим, неретко употребљавају и када о себи говоре у трећем лицу, што можемо означити и као специфични вид комуникацијске „моде” тога доба, што показују следећи примери:

Море, стиже друг, ти знаш да сам увек бар пола минута био бржи од професора кад треба стићи на час; Шта мислиш, обрати ми се Раша, могао би друг да се боље дотера, знаш, према оделцету требало би и ципеле...

Иако је делимично синонимна именици друг, именица пријатељь у нашем корпусу употребљава се у потпуно друкчијим ситуацијама. Њихова дистрибуција показује изузетну правилност: именица друг користи се у обраћању блиским особама, док се именица пријатељ употребљава у обраћању непознатим особама, и то од стране необразованих људи:

Mоре, пријатељу, поштеније је и овако него да се мува около, додаде други. 
Осим лексеме пријатељ, за обраћање непознатим особама у нашем корпусу постоје и именице са значењем животног доба којима старији ословљавају млађе:

Моје силне невоље прекиде директор: - Хоћеш ли ти, мали, и овде да будеш добар ђак, као што си био у гимназији?; Наплати, момак, долази воз.

Како се показује, функција апелатива у разговорима није само одржавање комуникације, него и уношење додатне димензије молбе, уверавања, прекора (Половина 1987: 59). Додатно, одабиром појединих апелатива у разговорном функционалном стилу истиче се и статус говорника у односу на саговорника.

\section{2. Специфична лексика и устаљене форме у говору омладине}

На лексичком нивоу, у Къизи сећања посебно се издвајају архаизми, историзми, омладински жаргон и еуфемизми. Док су архаизми и историзми лексички слој који је условљен временом настанка рукописа, жаргонизми и еуфемизми представљају избор говорника са циљем исказивања припадности социјалној групацији, те их сматрамо функционалностилски дистинктивним јединицама. Међутим, оне имају опозитну функцију: жаргонизми су показатељ „прогресивности” и помодарства омладине, а еуфемизми су знак припадности образованом слоју традиционалних схватања будућих носилаца просветне струке.

Присуство историзама и стилски обележених речи као што су архаизми (понекад су то истовремено и дијалектизми) показаћемо следећим примерима:

Збуњен и уплашен, а мало и посрамљен, изашао је из воде, не само мокар као миш него и блатњав као ћерамиција; Носио га је [џепни сат] у предњем џепићу брич-nанталона, привезаног нарочитим гајтаном што му га је исплео отац-абаиија; Најјевтинији интернат у земљи: тридесет пет банки месечно, може и на почек; Лежерно претражује, па, извадивши двобанку, пружа је дечаку;

Вероватно је био дустабанлија; У једном залатку стоји проседи господин; Са себе збацио излизано сукнено одело са браон пругама и кафени шешир са избледелом траком, ставио машну, дотерао зулуфе у шпиц, скоро да их је саставио са наусницама. А ове је, опет, нагарио нагорелом шибицом...; протурисмо главе кроз шубер кухиње; Причекај само да скокнем у ресторацију.

Анализирајући експресивну лексику урбаног омладинског жаргона и поредећи је са експресивном лексиком српског језика из дугог претходног периода (око 150 година), С. Ристић закључује да у овој сфери постоји континуитет „који се одржава не само у начинима творбе него и великом броју заједничких јединица" (Ристић 2000: 270). У нашем корпусу се издваја специфична жаргонска лексика као одлика припадности групи: интерции, интернатлије (ученици који живе у интернату), екстерни или екстерци (ученици који похађају Школу али не станују у интернату), благодејанци (ученици који 
примају благодејаъе односно државну стипендију која се заснивала на успеху и материјалном стању родитеља). И неки од устаљених израза уско су везани за школски живот и школску терминологију. Неке од таквих форми у највећем делу задржавају своје значење (нпр. радити нешто или бити кажњен у дуету), док се значење неких модификује и само парцијално одговара примарном (нпр. „Баш кад су се најлепше брчкали као свети дух се појавио васпитач Чика Рака", где се поређење као свети дух односи само на тихо, неопажено појављивање). На овом пољу, видљива је компонента емоционалности, која је предуслов да школска терминологија промени регистар и постане део свакодневног вокабулара. Наиме, доминирају термини из области веронауке, коју ученици изразито нису волели, и музике, која им је била омиљени предмет.

Специфична лексика везана за школски живот јавља се и у наредним примерима (прва група). Овој групи би припадао и пример (који наводимо) са глаголом (за)врбовати као део лексике свакодневног школског живота тога доба (вероватно под утицајем политичке атмосфере и начина изражавања у тој области), док се најбројније лексеме везане за говор младих могу сврстати у фонд опште неформалне лексике (друга група примера). Заступљена је и жаргонска лексика (трећа група):

Говорећи о детаљу када је лисица послужила чорбу дугокљуној гошћи, у плитком тањиру, предавач откри апликацију, остави је тренутак да је деца разгледају, и настави; Сем нас екскурзиста, Југословена скоро да нема; Професор историје Миковић [...] стоји у дворишту у друштву неколико ученика („жртвица”) и нешто филозофира, разглаба; Кружоку је најпре припадао и Душан Јовановић, али је касније испао - приграбила га друга струја. Са нама је неко време био и Слободан Крстић, звани Маријана, кога је, по нашем уверењу, директор Ристић био заврбовао за денуцијанта...

Е јеси, бре, права врдалама, није погрешио онај ко те тако назвао!; Успут попушимо по пола ,, ибрића” и кренемо путем према селу Штипљу; Шта му би те нас овако „испраши"; Остали смо без вечере. Начисто; За мене су сви попови били нека врста баксуза; И тако, погибосмо, ето, ко од шале; Најинтересантније је било кад сам се загрејао за цртање гробља под месечином; Седећи за столом поред прозора (полуотвореног, пошто је топло време после дванаест сати будног и активног стања, метнем главу на књигу и, вероватно, задремам.

И док не сазнах да се не каже „опреза” него „опрез”, шетао ме тако да ми је још само требало да ми неко отпева „Коларићу, панићу, плетемо се самићу...”; А ти распалио па тетка Мици једно, а њему друго. Мислиш ли ти да он није слушао како си тетка Мицу уверавао; Ја сам био полупијан, односно тек „ћефнут”, и понашао сам се доста нормално, али је било таквих који су се једва држали на ногама, које су вукли у учионицу, који су падали на под пред очима самог директора, повраћали.

Контекст и комуникативна ситуација могу предодредити статус одређене лексеме. Тако у примеру „према оделцету требало би и ципеле” и лексема оделце може се окарактерисати као нека врста омладинског жаргонизма, где је видљива додатна семантичка компонента која има „функцију деловања на адресата" (Јовановић 2005: 101). Оделие је, наиме, уколико се посматра нарочито у оквиру времена у којем се изговара (када су ученици носили сељачка одела и опанке, а грађанска одела била реткост, о чему у Кюизи сећања 
постоје сведочења), хипокористик који треба додатно да упути и на понос власника и лепоту одеће.

По бројности се међу експресивном лексиком издвајају називи којима се жигоше слобода жена у вези са хетеросексуалним односима, која се „и даље традиционално оцењује као кршење јавног морала" (Ристић 2000: 270). Међутим, у Књизи сећања нема таквих назива. Истиче се младићко неискуство у контакту са девојкама. То објашњавају животом у мушком интернату (и читава школа била је мушка) и веома ограниченим временом за изласке у град (према сведочењу некадашњих ученика који су ову школу похађали много касније, шездесетих година двадесетог века, када је школа већ била мешовита, у време предвиђено за шетњу градом на јагодинском корзоу је чак и тада био присутан дежурни наставник).

Не само да у Књизи сећања нема негативно обојених експресивних назива за особе женског пола, него се и ретка помињања везана за сексуални живот еуфемизирају:

„У градићу су постојале две или три куће за пружање љубавних услуга. Те услуге је, зачудо, потражио релативно мали број интернатлија, и то не због цене (20 или 30 динара), колико због невероватно простачког понашања дама које те услуге нуде, због могућности да се младић у првом контакту - обрука (што се још како дешавало) па да после, индискрецијом тих жена буде у интернату предмет пецкања, шала, подсмеха...”

Чинови блиски оговарању, чија је типична али не и једина форма наративна (Милосављевић 2010: 44), такође обилују еуфемизмима. У наредном примеру еуфемизација се не односи на конкретне податке (о ванбрачној вези и детету), већ на догађај којим је веза кулминирала пред широком публиком:

Петровић је имао недоличан приватни живот. Имао је дете са учитељицом из Мајура, која је од њега захтевала брак. У једној прилици, на прослави десетогодишњице пробоја Солунског фронта, док је Веса Вукићевић држао говор, др Петровић је стајао у друштву госпођице Косовљанин, која је била из имућне породице а иначе није била школована. Учитељица је пришла и кишобраном дотакла по глави Петровићеву даму, после чега су се обоје удаљили са свечаности.

Иако, како се види, у записима нема израженог пуризма који одликује отпор према страним речима, „иновацијама, академизам и конзерватизам, у смислу 'повратка на изворе"” (Клајн 2008: 153), очигледно је и да аутори брину о култури изражавања, посебно на плану избегавања вулгаризама и директног описивања непријатних момената.

Устаљени изрази, поређења и фразеологизми такође карактеришу текстове у Књизи сећања. На скали фиксираности (Половина 1999: 197) овакви изрази крећу се од формула, које су „говото непроменљиве, попут Добар дан" (Исто, 197), преко пословица и изрека. Следе фразеологизми, идиоми и колокације (Исто, 198). Само неки од оваквих израза нису уобичајени и у данашњем разговорном стилу (прва група примера), док се већина, у идентичном или нешто измењеном облику, задржала у свакодневној комуникацији до данас (примери друге групе у којој су посебно издвојене поредбене конструкције): 
(1)

Знаш, друшкане, сат и жена се ником не дају; Излетесмо из шубера као пампури из флаше; Све је то што Ви фанатично заступате и нама страствено говорите мужа јариа у pememo! $!^{4}$

(2)

И тако, погибосмо, ето, ко од шале; Огласи се друго звоно, а предавач који као да се дотле држао за кваку, груну на врата као из топа; У следећем делу секунде, покренут свим опругама мог система самоодбране, као из топа избачен, појурим у правцу (отвореног) прозора; Одједном се тргнем, као зещ: куц-куц у прозорско стакло; Ко без душе банусмо у празну трпезарију;

А он је то изговарао тако [...] да нас је из коже изводио; Е, сад нешто отпевај, додаде професор, а ја из петних жила запех: „Од Босне се турска војска љута диже”; кад бих пролазио поред попа, хватао сам се за дугме „да ме не бије малер”; Народна кола су им уила у крв; А он, у тегет „цивилном” оделу. [...] Ни онај Суља, ни дај боже. Просто човек да не верује. [...] Тешко би га и његов Велизар препознао; Ма, 'ајде, ита ти пада на памет, рекох, воз само што није стигао; Мени, међутим, ни на крај памети није било да послушам оца; Чак и запева „Зденчице, ја љубим уста твоја”, мртав 'ладан, упркос журби путника; Требало је „стиснути петљљ” и отићи на гробље. Наравно да нисам имао „три чисте” да идем сам, позвао сам своје добре другове и са њима одлазио више пута. Чували смо једни другима страх; Честитам ти, ово је предавање, а не само: причам ти причу.

Да су овакви изрази били жаргонски обојени или имали статус устаљених форми као део неформалне комуникације разговорног стила, показује и то што су их аутори текстова стављали под знаке навода или њихову идиоматизацију сугерисали коментаром „како/тако се (то) каже”. Осим претходно наведених примера, овај поступак документујемо и наредним:

Једног друга смо сакрили на дрвима у дворишту, где је лежао „мртав пијан”, како се то каже; Друштво је друштво - „и калућер се у друитву жени” - како се то каже.

\section{3. Култура говора учитељаца у периоду између два светска рата}

Иако су лексички и фразеолошки слој разговорног стила учитељаца у периоду између два светска рата блиски данашњем стању, њихови писани искази сведоче о изузетно високом нивоу језичке културе. Рукопис Књига сећањ $а$ јасно показује да су ученици јагодинске Учитељске школе и у потпуно неформалним приликама бирали речи, користили се највише страндардним језиком, и да се разговорни стил у њиховој комуникацији приближава узору говорне културе. Шта би могли бити узроци томе?

Питомци јагодинске учитељске школе овакве говорне навике нису донели из породичног окружења. Они нису били завидног социјалног положаја ни имовинског стања, што показују извештаји о раду Школе. У једном од њих наводи се да 83 ученика потичу из породица трговаца, гостионичара,

\footnotetext{
${ }^{4}$ Н. Вуловић (2019: 275) наводи овај фразеологизам који има значење „радити узалудан, бескористан посао".
} 
занатлија, земљорадника и служитеља, од чега су најбројнија деца земљорадника (чак 34). С друге стране, само 32 ученика су из свештеничких, наставничких и чиновничких породица.

Претпоставку да је у неговању културе изражавања могла превагнути стручност професора српског језика у великој мери оповргавају поуздани архивски подаци. Професори су предавали по више предмета, а примарно образовање најчешће се није односило на српски језик (у то доба Лука 3рнић, Милан Павловић и Емило Цветић, иначе чувени историчар, предавали су уз српски језик с књижевношћу и историју, земљопис, немачки језик, в. Двадесетпетогодишњиияа МУШЈ: 43-45).

Упркос свему томе, ђаци су одржавали књижевне састанке, писали стручне чланке, имали колективно чланство, иако највећим делом сиромашни, као чланови добротвори у Матици српској и Српској књижевној задрузи. Уз подршку Школе издавали су и неколико часописа. Једино што би се могло одредити као поуздани фактор такве бриге о сопственој култури изражавања јесте статус самог занимања за које су се школовали. Судећи према извештајима, архивској и мемоарској грађи, углед и друштвени положај просветних радника у то доба били су изузетни. На путу да постану „народни просветитељи”, питомци Учитељске школе трудили су се да у свакој прилици буду достојанствени, одмерени, уредни, а пре свега да воде рачуна о свом изражавању. У Књизи сећањ $а$ чак је забележена епизода о томе да би старији ђаци чвргом опомињали новопридошле уколико би начинили падежну или какву другу погрешку. А у личној преписци Драгутин Прокић, некадашњи ђак Школе а касније редовни професор универзитета, каже о директору школе у време на које се односи наша грађа, доктору педагогије Драгољубу Петровићу: „Кад је пролазио Јагодином, мушкарци су скидали шешире и капе, даме му се клањале, а деца говорила Љубим руке. [...] После рата, кад би директори школа пролазили 'Светозаревом', нико их није примећивао и зарезивао ни колико врана скелеџију” (Прокић, Писмо 1993).

Нема сумње да је кључни узрок разлике у свакодневном изражавању ондашњих ђака-учитељаца и данашње омладине управо у уважавању просветне струке, угледу и достојанству које је она тада уживала. Своју привилегију да се школују за наставничка занимања ученици су бранили, између осталог, и изузетном бригом о свом изражавању.

\section{ИЗВОРИ}

Годишњи извештај 1908/1909: Српска Краљевска Мушка учитељска школа у Јагодини, Једанаести годишњи извештај 1908-1909. иколска година, уз помоћ више наставника приредио Сретен М. Аџић, управитељ.

Двадесетпетогодишњица МУШЈ: Двадесетпетогодињица Мушке учитељске школе јагодинске, са 21 сликом у тексту, израдио Јосиф В. Стојановић, управитељ. Јагодина, 1924. 
Књига сећања: Кьига сећања (Учитељска школа у Јагодини 1920-1940. у сећағу њених ученика), текстове прикупио и приредио Драгиша Марковић, 1988, (рукопис).

Прокић, Писмо 1993: Писмо др Богољуба Прокића Нинославу Станојловићу, 27. јул 1993.

\section{ЛИТЕРАТУРА}

Вуловић 2019: Наташа Вуловић, Рад - нерад / Конвенционални суд у систему вредности у српском језику и култури, Научни састанак слависта у Вукове дане, 48/1, 271-278.

Ивић 1997: Милка Ивић, Проблеми норме у књижевном језику, у: О Вуковом u вуковском језику, Друго, допуњено издање, Београд: Библиотека XX век, 145-157.

Ивић 2005: Milka Ivić, O srpskim partikulama PA i MA (iz perspektive i „fativne” i ,reaktivne” funkcije jezika), u: M. Ivić, O rečima. Kognitivni, gramatički i kulturološki aspekti srpske leksike, Beograd: Čigoja štampa (Biblioteka XX vek), 83-93.

Јовановић 2005: Владан Јовановић, Неки аспекти прагматичке употребе деминутивних јединица, Наш језик, XXXVI/1-4, 100-103.

Клајн 2008: Иван Клајн, Пуризам и антипуризам у данашњем српском језику, Јужнословенски филолог, LXIV, 153-176.

Кликовац 2008: Duška Klikovac, Iz problematike funkcionalnih stilova u srpskom jeziku, u: Jezik i moć: ogledi iz sociolingvistike $i$ stilistike, Beograd: Čigoja štampa (Biblioteka XX vek), 111-134.

Милосављевић 2010: Бојана Милосављевић, О наративној форми оговарања, Наш језик, XLI/1-2, 37-46.

Николић 2008: Видан Николић, Поштапалице у разговорном функционалном стилу - синтаксички и реторички аспекти, у: М. Ковачевић (ур.), Срnски језик, књижевност, уметност, књ. I (Српски језик у (кон)тексту), Крагујевац: ФИЛУМ, 101-111.

Половина 1987: Vesna Polovina, Leksičko-semantička kohezija u razgovornom jeziku, Beograd: Filološki fakultet Beogradskog univerziteta.

Половина 1999: Vesna Polovina, Semantika i tekstlingvistika, Beograd: Čigoja štampa.

Ристић 2000: Стана Ристић, Експресивна лексика у најновијем омладинском жаргону и у савременом српском језику (социолингвистички аспекти употребе и развоја), Наш језик, XXXIII/3-4, 257-272.

Ристић 2006: Стана Ристић, Раслојеност лексике српског језика и лексичка норма, Београд: Институт за српски језик САНУ.

Савић/Половина 1989: Svenka Savić, Vesna Polovina, Razgovorni srpskohrvatski jezik, Novi Sad: Institut za južnoslovenske jezike Filozofskog fakulteta.

Силић 2006: Josip Silić, Funkcionalni stilovi hrvatskoga jezika, Zagreb: Disput. 
Тошовић 2002: B. Tošović, Funkcionalni stilovi, Grac: Institut für Slawistik der Karl-Franzens-Universität.

Хајмз 1980: Del Hajmz, Etnografija komunikacije, Beograd: BIGZ.

\author{
Ilijana R. Čutura
}

\begin{abstract}
PRESENCE AND CHARACTERISTICS OF COMMUNICATION STYLE IN THE UNPUBLISHED MANUSCRIPT THE BOOK OF REMEMBRANCE
\end{abstract}

\title{
Summary
}

The paper studies the presence of communication style in an unpublished manuscript The Book of Remembrance (Teacher Training School in Jagodina from 1920 to 1940, In Students' Testimonies). The manuscript, which is a worthy testimony about the Teacher Training School in Jagodina, includes texts collected by a former student, Dragisa Markovic.

Stylistically diverse texts are analyzed in terms of the dominant characteristics that connect them. These are, above all, more or less literary shaped private diary testimonies or short memoir paragraphs. The texts indicate a degree of stylistic and functional-stylistic coherence mainly because their authors are of similar age and education level, and are predominantly male. The analysis of selected texts indicates that communication style of young educated people of the period between the two world wars relied to a large degree on the standard Serbian language, possessed somewhat fictional traits, and used euphemisms amply to avoid vulgar language and direct negative judgement.

Key words: communication style, language culture, dialogue, sayings, addressing others, euphemisms. 